\title{
ACTIVATION AND CHARACTERIZATION OF ALGERIAN KAOLINITE, NEW AND GREEN CATALYST FOR SYNTHESIS OF POLYSTYRENE AND POLY(1,3-DIOXOLANE)
}

\author{
Sarra Sabrina Aiche ${ }^{1}$, Hodhaifa Derdar ${ }^{1,2,}{ }^{凶}$, Zakaria Cherifi ${ }^{1,2}$, \\ Mohammed Belbachir ${ }^{1}$, Rachid Meghabar ${ }^{1}$
}

https://doi.org/10.23939/chcht15.04.551

\begin{abstract}
In the present work we have explored a new catalyst prepared with Algerian clay and a new method to synthesise polystyrene and poly(1,3-dioxolane). This technique consists of using Algerian modified clay $\left(\right.$ Kaolinite- $\left.\mathrm{H}^{+}\right)$as a green catalyst. Kaolinite- $\mathrm{H}^{+}$is a proton exchanged clay which is prepared through a simple exchange process. Synthesis experiments are performed in bulk. The polymerization of styrene in bulk leads to the yield of $83 \%$ at room temperature with the reaction time of $3 \mathrm{~h}$. Molecular weight of the obtained polystyrene is calculated by ${ }^{1} \mathrm{H}$ NMR and is about $2196 \mathrm{~g} / \mathrm{mol}$. Polymerization of (1,3-dioxolane) is carried out at room temperature with the reaction time of $3 \mathrm{~h}$ and polymerization yield of $91 \%$. The calculated molecular weight of the obtained poly(1,3-dioxolane) is about $573 \mathrm{~g} / \mathrm{mol}$. The structure of the obtained polymers is confirmed by FT-IR and ${ }^{1} \mathrm{H}$ NMR. The modified clay $\left(\right.$ Kaolinite- $\left.\mathrm{H}^{+}\right)$is characterized by FT-IR, XRD and SEM analysis.
\end{abstract}

Keywords: Kaolinite- $\mathrm{H}^{+}$, Algerian clay, eco-catalyst, polystyrene, poly(1,3-dioxolane).

\section{Introduction}

The use of acid modified clay as a way to promote cationic polymerization has been the subject of numerous reports [1]. It provides a greener, less toxic and a more cost-effective alternative to the conventional cationic initiator such as metal based Lewis acids [2] and Bronsted acids [3]. Besides, these acid activated clays are more stable to the air and suffer less from oxidation trends [4].

\footnotetext{
${ }^{1}$ Laboratoire de Chimie des Polymères, Département de Chimie, FSEA, Université Oran1

Ahmed Benbella BP N 1524 El M’Naouar, 31000 Oran, Algeria

${ }^{2}$ Centre de Recherche Scientifique et Technique en Analyses PhysicoChimiques (CRAPC),

BP 10 384, Siège ex-Pasna Zone Industrielle, Bou-Ismail CP 42004, Tipaza, Algeria

hodhaifa-27@outlook.fr

(C) Aiche S., Derdar H., Cherifi Z., Belbachir M., Meghabar R., 2021
}

The Smectites clays were known for a long time for their significant ability to catalyze efficiently various organic reactions [5]. Gómez-Sanz et al. [6] reported a work emphasizing the role of raw saponites and montmorillionites as acidic catalyst. They demonstrated that acid clay was an efficient and recyclable catalyst for a Mannish reaction to synthesis $\beta$-amino ketones.

Although the preparation of clay/polymer nanocomposites was a well-known process that has been wildly described [7], the use of clays as initiators for polymerization processes on the other hand was limited. Nevertheless, the work of Wang et al. [8] on the polymerization of phenolic compounds using montmorillonite, illite and kaolinite is worth mentioning for its pioneer aspect. It was only in the early $20^{\text {th }}$, thanks to the work of Belbachir et al. [9], that the use of clays as a way to promote cationic polymerizations became a common trend. During the last two decades, there have been several reports describing the use of acid activated montmorillonite as a cationic initiator for different polymerization and copolymerization processes of numerous linear and cyclic monomers including isobutylene [10], styrene [11], $N$-vinyl2 -pyrrolidone [12], $\beta$-pinene [13], glycidol [14], and dodecamethylcyclohexasiloxane [15].

Kaolinite, which is the main mineral contained in kaolin deposit clays, is also known to have various applications such as nanofillers for the preparation of polymer nanocomposites [16], fillers in the rubber and paper industries [17], pigments in paint [18], and ceramics [19]. However, we did notice through our researches that the use of kaolinite as catalyst was somehow limited. Its largest use was as catalyst subtracts in catalytic cracking processes [20]. In fact, kaolinite is considered as less reactive in comparison with other clays families such as smectites, palygorskite and sepiolite [21]. There are only few reported works on the use of kaolinite as a catalyst to promote polymerization [22]. Wang et al. [23] investigated the effect of kaolinite in the formation of hydroquinonederived polymers. Zhao et al. [24] also studied the catalytic aspect of kaolinite in the preparation of polystyrene. 
Generally, almost all the catalysts used for the preparation of polymers present great environmental problems, as they are corrosive. The main drawbacks of the application of zinc and silver compounds as well as Lewis acids are the difficulty to handle and complicated separation. Moreover, zinc or silver compounds require environmental reconditioning [25]. In this work, we have described the preparation of new acid activated kaolinite clay as a potential cationic initiator for the polymerization of both linear and cyclic monomers. The catalytic activity of this clay was investigated through the synthesis of two different polymers: polystyrene and poly(1,3-dioxolane). The polymerizations were carried out under mild conditions with respect to the green chemistry principles.

By examining the literature, we found that the studies of the catalytic properties of Algerian kaolinite for polymerization of styrene and 1,3-dioxolane are practically nonexistent. The main purpose of this work is to study the properties of the modified kaolinite as a new and non-toxic catalyst for cationic polymerization of both linear and cyclic monomers. Kaolinite is preferred for its many advantages such as very low purchase price compared to other catalysts and easy removal of the reaction mixture, regenerated by heating to the temperature above $393 \mathrm{~K}$. FT-IR, XRD and SEM analysis confirm the acid activation of kaolinite. ${ }^{1} \mathrm{H}$ NMR and FT-IR analysis show that the polymerization of styrene and 1,3-dioxolane is successfully with Kaolinite- $\mathrm{H}^{+}$.

\section{Experimental}

\subsection{Materials}

Styrene (98\%), 1,3-dioxolane (97\%), methanol $\left(\mathrm{CH}_{3} \mathrm{OH}, 99.9 \%\right)$ and dichloromethane $\left(\mathrm{CH}_{2} \mathrm{Cl}_{2}, 99.8 \%\right)$ were supplied by Sigma Aldrich and used as received. Kaolinite (Algerian clay) was supplied in the raw state, Tounane (Algeria).

\subsection{Purification of Kaolinite}

The purification proceeds by washing the raw kaolinite with distilled water. The kaolinite is ground first and then sieved $(\delta<0.08 \mathrm{~mm}) .30 \mathrm{~g}$ of kaolinite are dispersed in 1 liter of distilled water $(2 \mathrm{wt} \%)$ and kept under magnetic stirring for $24 \mathrm{~h}$ at room temperature.
After stopping the stirring the suspension is decanted for a few minutes and filtered. This preliminary treatment allows the removal of water-soluble materials such as salts. The clay thus recovered is dried at $393 \mathrm{~K}$, then ground in a mortar, sieved $(\delta<0.08 \mathrm{~mm})$ and stored in a desiccator under vacuum.

\subsection{Preparation of Kaolinite- $\mathrm{H}^{+}$}

Kaolinite- $\mathrm{H}^{+}$is activated with a chloridric acid solution $(\mathrm{HCl})$ to give a kaolinite exchanged with protons, called $\mathrm{Kaol}-\mathrm{H}^{+}$. In an Erlenmeyer flask, crushed raw kaolinite $(30 \mathrm{~g})$ is dispersed in a volume of distilled water $(500 \mathrm{ml})$. The mixture is stirred for $20 \mathrm{~min}$ at room temperature. Then, a solution of chloridric acid $(0.5 \mathrm{M})$ is added. The solution thus obtained is maintained for 120 min under stirring. The mineral is filtered off and washed several times with distilled water up to $\mathrm{pH} 7$. After filtration, Kaol- $\mathrm{H}^{+}$is dried in an oven for $2 \mathrm{~h}$, at $378 \mathrm{~K}$ and is then crushed; the same experimental protocol is performed with $6 \mathrm{M}$ and $12 \mathrm{M} \mathrm{HCl}$. The composition of kaolinite is given in Table 1 and the results show that the amount of $\mathrm{Fe}_{2} \mathrm{O}_{3}$ is very important in the $\mathrm{KT}$ which gives it the red color except in the Kaolinite of Portugal. The amount of $\mathrm{SiO}_{2}$ is almost the same in all kaolinites. The amount of $\mathrm{Al}_{2} \mathrm{O}_{3}$ is almost the half. We also noted that there are traces of $\mathrm{MgO}$ and $\mathrm{K}_{2} \mathrm{O}$ in all kaolinites except in the Kaolinite of Portugal. Its structure is established by FT-IR, XRD and SEM analysis.

\subsection{Polymerization Procedure}

The reactions of polymerization of styrene and 1,3-dioxolane (Schemes 1 and 2) are carried out, in bulk using $\mathrm{Kaol}-\mathrm{H}^{+}$as a catalyst. In a flask containing $2 \mathrm{~g}$ of styrene, we added $5 \mathrm{wt} \%$ of $\mathrm{Kaol}^{-} \mathrm{H}^{+}$, which is previously dried for $30 \mathrm{~min}$ in the oven at $378 \mathrm{~K}$. The mixture is kept under stirring for $2 \mathrm{~h}$ at room temperature $(298 \mathrm{~K})$, the reaction mixture is dissolved in $\mathrm{CH}_{2} \mathrm{Cl}_{2}$, filtered, precipitated in cold methanol and dried in vacuum over night. The obtained polymer is a solid product. Then, the same experimental protocol is performed with $5 \mathrm{wt} \%$ of $\mathrm{Kaol}-\mathrm{H}^{+}$, but this time to polymerize 1,3-dioxolane.

Comparison of elementary compositions of kaolinite

\begin{tabular}{|c|c|c|c|c|c|c|}
\hline Elements & $\mathrm{Fe}_{2} \mathrm{O}_{3}$ & $\mathrm{SiO}_{2}$ & $\mathrm{Al}_{2} \mathrm{O}_{3}$ & $\mathrm{MgO}$ & $\mathrm{K}_{2} \mathrm{O}$ & LOI \\
\hline Algerian Kaolinite & 12.96 & 45.87 & 16.59 & 0.59 & 1.83 & 22.16 \\
\hline Kaolin of Tamazert $[26]$ & 0.98 & 57.7 & 37.98 & 0.33 & 1.07 & 1.94 \\
\hline Tunisian Kaolinite [27] & 1.63 & 58.49 & 22.32 & 0.62 & 1.42 & 10.94 \\
\hline Kaolin of India $\quad[28]$ & 0.86 & 45.81 & 37.72 & 0.32 & 0.03 & 13.56 \\
\hline Kaolin of Brazil [29] & 0.84 & 45.56 & 36.63 & 0.04 & 0.10 & 16.48 \\
\hline Kaolin of Portugal $[30]$ & 0 & 53.11 & 46.37 & 0 & 0 & 0.52 \\
\hline
\end{tabular}




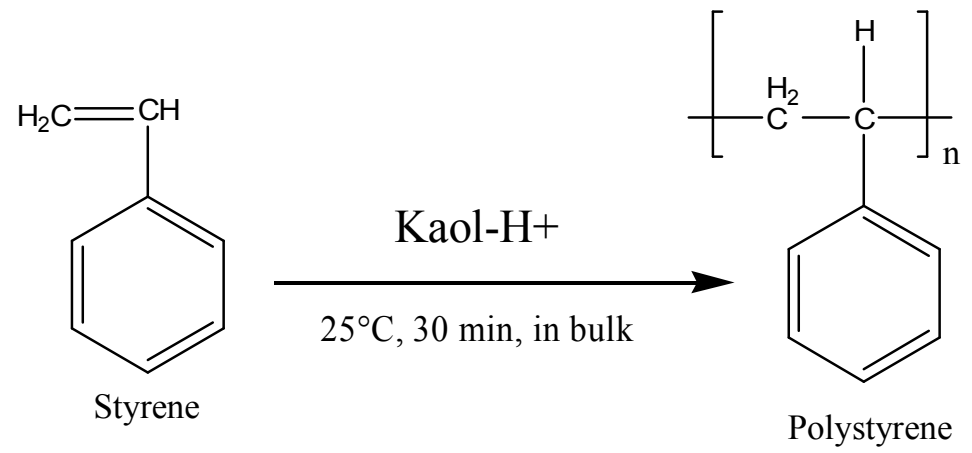

Scheme 1. Polymerization of styrene catalyzed by Kaol- $\mathrm{H}^{+}$<smiles>C1COCO1</smiles>

1,3 Dioxolane

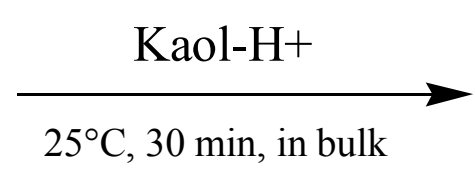

Scheme 2. Polymerization of 1,3-dioxolane catalyzed by Kaol- $\mathrm{H}^{+}$
Regarding the kinetic study, the same procedure described above was repeated by changing the percentage of the catalyst and the time of the reaction, in order to find the optimal reaction conditions.

\subsection{Characterization}

The X-Ray powder diffraction profiles for pressed powder samples were recorded on a D8 Discover Bruker diffractometer using $\mathrm{Cu}-\mathrm{K} \alpha$ radiation $(\lambda=1.5418 \AA)$. The surface morphology of the modified clay was observed by FEG-SEM on a JEOL 7001F electron microscopy. FTIR absorption spectra were recorded on an Alpha Bruker FTIR spectrometer. NMR is a very powerful analytical method for the elucidation of chemical structures. ${ }^{1} \mathrm{H} N M R$ spectra are recorded on a Bruker-Avance 300MHZ apparatus in Deuterated Chloroform.

\section{Results and Discussion}

\subsection{Characterization of Kaolinite- $\mathrm{H}^{+}$}

Fig. 1 shows the FT-IR spectrum of raw kaolinite and kaolinite washed with distilled water and dried at $393 \mathrm{~K}$. We noted a change in two spectrums at the bands of 3397 and $3697 \mathrm{~cm}^{-1}$, which correspond to the $\mathrm{OH}$ bands vibration. These bands disappear during the drying of kaolinite at $393 \mathrm{~K}$ indicating the disappearance of the $\mathrm{OH}$ molecules.
The bands at 3397 and $3697 \mathrm{~cm}^{-1}$ correspond to the frequency of $\mathrm{O}-\mathrm{H}$ stretching vibrations and the peak at $3697 \mathrm{~cm}^{-1}$ is attributed to the elongation of the inner surface hydroxyl groups. The band located at $3622 \mathrm{~cm}^{-1}$ corresponds to the elongation of the internal hydroxyl group of kaolinite. The lower frequency bands, appearing around $1400 \mathrm{~cm}^{-1}$, correspond to the Si-O-Si elongation vibrations, the band that appears at $911 \mathrm{~cm}^{-1}$ corresponds to the vibrations of the $\mathrm{Al}_{2}-\mathrm{OH}$, and the band located at $795 \mathrm{~cm}^{-1}$ can be attributed to the asymmetric and symmetric elongation vibration of the Si-O-Si group. All these expected absorption bands confirm that the structure of the compound is in a good agreement with vibration values obtained from the literature [31].

The X-ray diffractograms of raw Kaolinite and Kaolinite- $\mathrm{H}^{+}$are shown in Fig. 2. The Figure shows a slight change in the interlayer distance according to Table 2 after the quartz extraction. We also note that in the diffractogram (A) the intensity of the quartz is 3232 counts while in the diffractogramme (B) the intensity went down to 637 counts.

The SEM images of raw-Kaol and modified Kaolinite $\left(\right.$ Kaol- $\left.\mathrm{H}^{+}\right)$are shown in Fig. 3. These images are very similar to those obtained by M. Hernandez [32]. The SEM images showed that the morphology of kaolinite was retained after modification by the $\mathrm{HCl}$ acid. The particle sizes of all samples are about $1-10 \mu \mathrm{m}$. These particles exhibited bulky flakes and aggregated disorderly form confirming the layered structure of clay, indeed the modified clays are expected to have a similar morphology. 


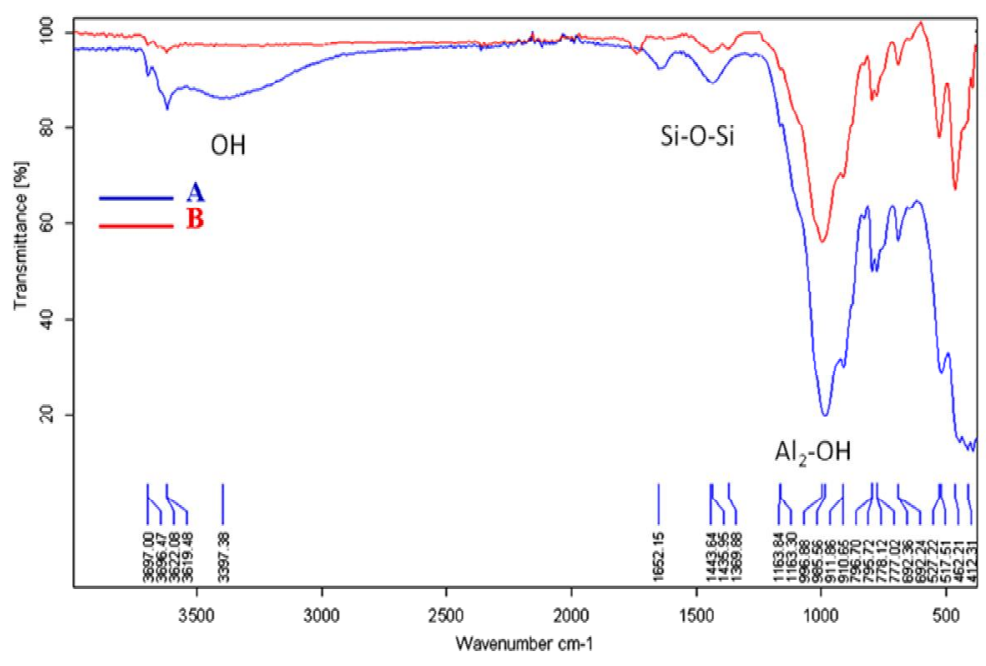

Fig. 1. FT-IR spectra of raw-Kaol (A) and Kaol- $\mathrm{H}^{+}$(B)

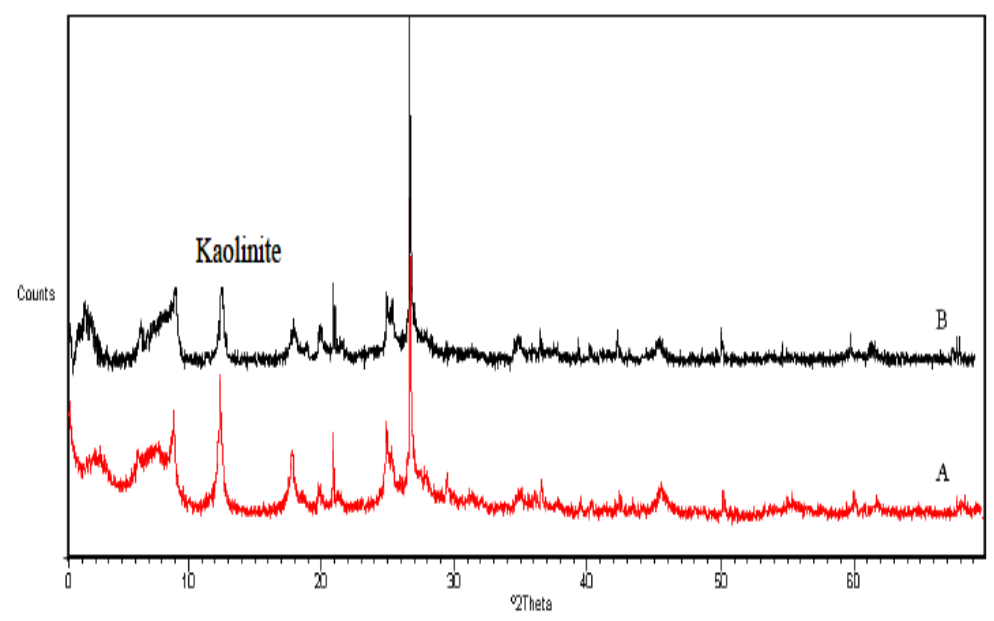

Fig. 2. X-ray diffractograms of raw-Kaol (B) and Kaol- $\mathrm{H}^{+} 0.25 \mathrm{M}$ (A)

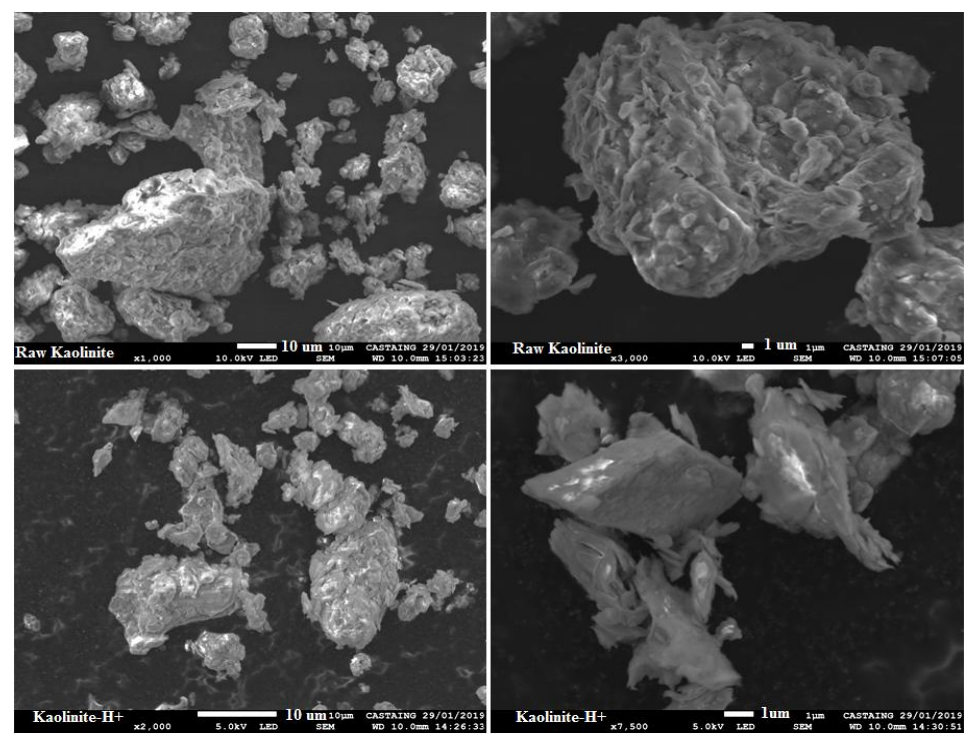

Fig. 3. SEM images of raw-Kaol and Kaol- $\mathrm{H}^{+}$ 
Table 2 FT-IR spectrum of polystyrene (Fig. 4) shows the following

Change in interlayer distances before and after acid activation

\begin{tabular}{|c|c|c|}
\hline & A & B \\
\hline Halloysite $10 \AA$ & 9.98 & 10.07 \\
\hline Halloysite 7 $\AA$ & 4.25 & 4.48 \\
\hline Kaolinite & 7.13 & 7.20 \\
\hline Quartz & 3.38 & 3.35 \\
\hline
\end{tabular}

\subsection{Characterization of the Obtained} Polymers (Polystyrene and Poly(1,3Dioxolane))

\subsubsection{Fourier Transform Infrared Spectroscopy (FT-IR)}

FT-IR spectra of polystyrene and poly(1,3dioxolane) are shown in Figs. 4 and 5, respectively. The characteristic bands: the bands at 2848 and $2919 \mathrm{~cm}^{-1}$ correspond to the aliphatic $\mathrm{C}-\mathrm{H}$ vibration frequencies and the band at $3024 \mathrm{~cm}^{-1}$ corresponds to the aromatics $\mathrm{C}-\mathrm{H}$ elongation vibrations. The peaks at 690 and $760 \mathrm{~cm}^{-1}$ correspond to the deformation of a substituted aromatic ring and the disappearance of the $1630 \mathrm{~cm}^{-1}$ band corresponding to the frequency of elongation vibrations of the vinyl double bond of styrene, shows that the polymerization of styrene with $\mathrm{Kaol}-\mathrm{H}^{+}$has succeeded; the same result is obtained by N.Bensaada et al. [33].

FT-IR spectrum of poly(1,3-dioxolane) shown in Fig. 5 is characterized by different vibration bands; the bands between 2881 and $2956 \mathrm{~cm}^{-1}$ correspond to the vibrations of $\mathrm{C}-\mathrm{H}$ of methyl group. The band at $1450 \mathrm{~cm}^{-1}$ is assigned to the vibrations of $\mathrm{C}-\mathrm{C}$. The bands at 1018 and $1300 \mathrm{~cm}^{-1}$ are attributed to $\mathrm{C}-\mathrm{O}$ groups of ether functions. Similar results were obtained by M. Belbachir et al. [34].

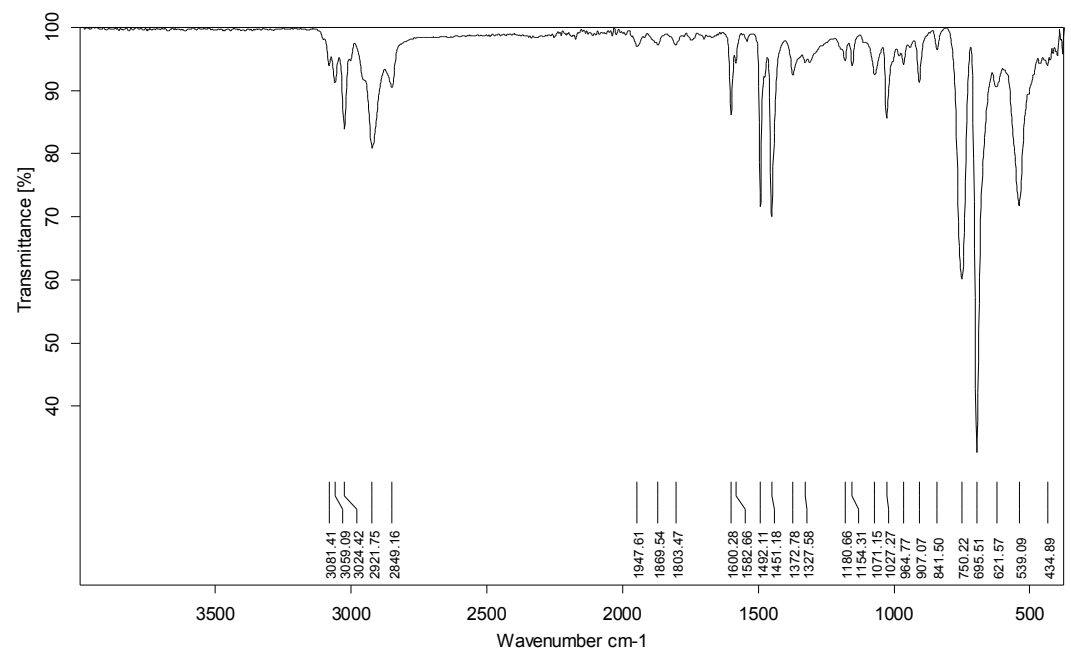

Fig. 4. FT-IR spectrum of the obtained polystyrene

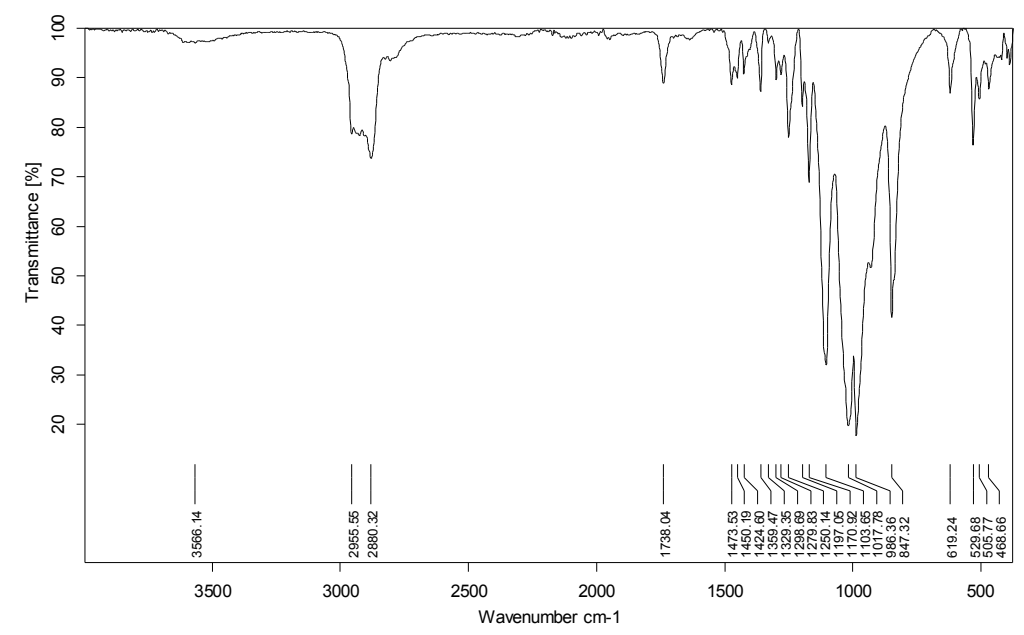

Fig. 5. FT-IR spectrum of the obtained poly(1,3-dioxolane) 


\subsubsection{Nuclear Magnetic Resonance of Proton $\left({ }^{1} \mathrm{H}-\mathrm{NMR}\right)$}

NMR spectrum of the obtained polystyrene is shown in Fig. 6. ${ }^{1} \mathrm{H}$ NMR spectrum of polymer was recorded in $\mathrm{CDCl}_{3}$ using a Bruker $300 \mathrm{MHz}$ apparatus at $298 \mathrm{~K}$ and gives the following information:

The ${ }^{1} \mathrm{H}$ NMR spectrum confirms the structure of the polymer obtained in this study. The signals between 6.6 and $7.3 \mathrm{ppm}$ are attributed to the aromatic protons. The peaks at 5 and $6 \mathrm{ppm}$ are the characteristic resonance of the protons resulted by the terminal double bond $(-\mathrm{C}=\mathrm{CH})$ of the main chain as large signal in the range of $1.5-2 \mathrm{ppm}$ and the terminal methyl groups at $1.2 \mathrm{ppm}$. The ${ }^{1} \mathrm{H}$ NMR spectrum of the obtained polystyrene is similar to that of polystyrene obtained with Maghnite- $\mathrm{H}^{+}$
[35], which clearly shows that the synthesis of polystyrene is successful with Kaol- $\mathrm{H}^{+}$.

${ }^{1} \mathrm{H}$ NMR spectra of poly(1,3-dioxolane) is shown in Fig. 7. The polymerization is carried out in bulk at $298 \mathrm{~K}$ for $30 \mathrm{~min}$, the peak "b" at $4.7 \mathrm{ppm}$ and the peak "a" at $3.71 \mathrm{ppm}$ correspond to protons in methyl group $(\mathrm{C}-\mathrm{H})$. The peak at $2 \mathrm{ppm}$ is a characteristic resonance of the proton resulted by the terminal hydroxyl group $(\mathrm{OH})$.

The molecular weight of the obtained polymers determined by ${ }^{1} \mathrm{H}$ NMR spectrum is reported in Table 3 .

Table 3

\section{Molecular weight of the obtained polymers}

\begin{tabular}{|c|c|}
\hline Product & Molecular weight, $\mathrm{g} \cdot \mathrm{mol}^{-1}$ \\
\hline Polystyrene & 2196 \\
\hline Poly(1,3-dioxolane $)$ & 573 \\
\hline
\end{tabular}

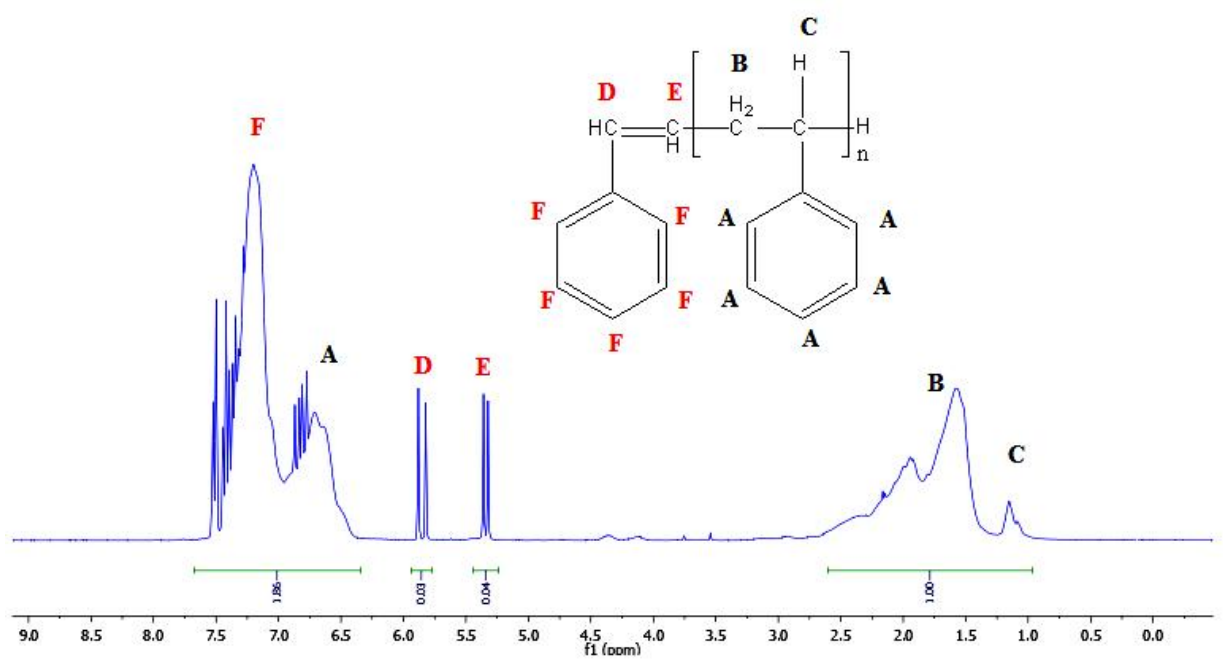

Fig. 6. ${ }^{1} \mathrm{H}$ NMR spectrum of the obtained polystyrene

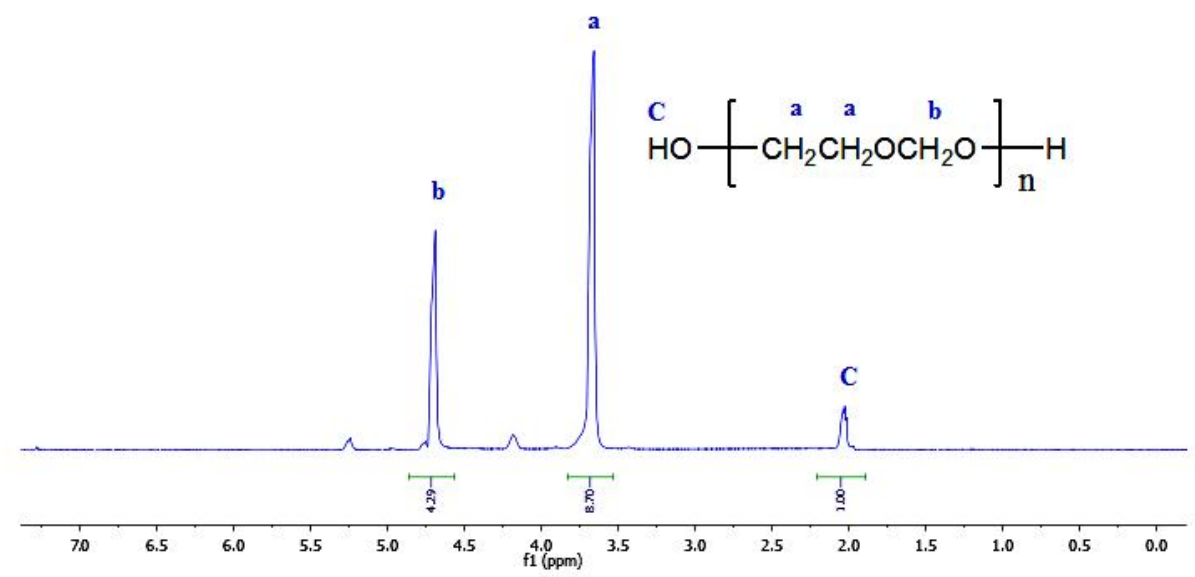

Fig. 7. ${ }^{1} \mathrm{H}$ NMR spectrum of the obtained poly(1,3-dioxolane) 


\subsection{Determination of Optimal Reaction Conditions}

The objective of this part is to study the kinetic of the polymerization of styrene and 1,3-dioxolane with $\mathrm{Kaol}-\mathrm{H}^{+}$, which consists in varying separately different parameters including the quantity of the catalyst and the reaction time, in order to know their influence on the yield of the obtained polymers and to find the optimum conditions of the reaction. The \% yield of the obtained polymers is calculated by a simple weighing according to the following equation: yield $(\%)=\left(M_{0} / M_{1}\right) \cdot 100$, where $M_{0}$ is a weight of the obtained polymer; $M_{1}$ is a weight of the initial monomer.

\subsubsection{Effect of Kaol- $\mathrm{H}^{+}$amount on the yields of polystyrene and poly(1,3-dioxolane)}

Fig. 8 shows the effect of the catalyst amount on the yield of the obtained polymers. The polymerization reactions were carried out at $298 \mathrm{~K}$ for $30 \mathrm{~min}$ using various amounts of $\mathrm{Kaol}^{-} \mathrm{H}^{+}(2,5,7,10$, and $15 \mathrm{wt} \%)$, the reactions were carried out in bulk. Fig. 8 shows that the yield of polymers increased with the amount of $\mathrm{Kaol}-\mathrm{H}^{+}$. The yield increases according to the quantity of Kaol- $\mathrm{H}^{+}$ up to the optimal point, which corresponds to $15 \mathrm{wt} \%$. This behavior is explained by the increase of active sites available in $\mathrm{Kaol}-\mathrm{H}^{+}$responsible for the initiation and acceleration of the reaction until the saturation of these sites. After the reaction the solid catalyst is totally regenerated by simple filtration; similar results were obtained by Belbachir and coworkers using Maghnite- $\mathrm{H}^{+}$ as a catalyst [36].

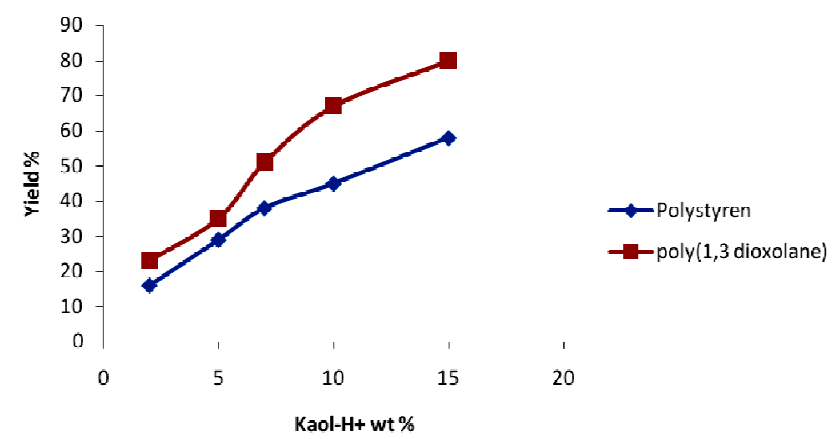

Fig. 8. Effect of the Kaol- $\mathrm{H}^{+}$amount on the yield of the obtained polymers

\subsubsection{Effect of time on the yield of the obtained polymers}

Fig. 9 shows the yield of the polymers versus synthesis time for polystyrene and poly(1,3-dioxolane) using $\mathrm{Kaol}-\mathrm{H}^{+}$as the catalyst. As the Figure shows, at the end of $3 \mathrm{~h}$, reaction takes place quickly, reaching the best yields $(83 \%$ for polystyrene and $91 \%$ for poly $(1,3$ dioxolane)) in the presence of $10 \mathrm{wt} \% \mathrm{wt}$ of $\mathrm{Kaol}-\mathrm{H}^{+}$at $298 \mathrm{~K}$. After this time, the reaction slows down gradually, and the yield becomes almost constant. This behavior is explained by the nature of the reaction conducted in bulk.

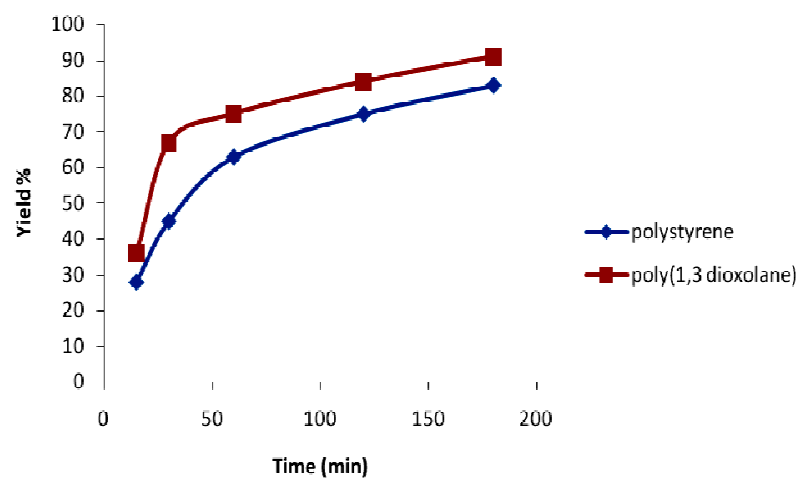

Fig. 9. Effect of the reaction time on the yield of the obtained polymers

\section{Conclusions}

In the present work, we have developed a new and green catalyst to polymerize vinylic and cyclic monomers. These materials were prepared using an Algerian clay $\left(\right.$ Kaolinite- $\left.\mathrm{H}^{+}\right)$, that could be used as green and ecocatalyst. The synthesis of polystyrene and poly(1,3dioxolane) over the Algerian Kaolinite provides excellent results in bulk, at room temperature and in one step. The influencing factors on the synthesis reaction were studied, and the optimal reaction conditions were obtained and the yield achieved its maximum $83 \%$ for polystyrene and $91 \%$ for poly(1,3-dioxolane) with $15 \mathrm{wt} \%$ of Kaolinite$\mathrm{H}^{+}$at room temperature for $3 \mathrm{~h}$, according to increase in acidic active centers. The resulting products were perfectly characterized by FT-IR and ${ }^{1} \mathrm{H}$ NMR. Kaolinite$\mathrm{H}^{+}$is an efficient catalyst, cheap and environmentally friendly. Its use in the polymerization of vinylic and cyclic monomers leads to good results.

\section{References}

[1] Vilela C., Sousa A., Fonseca A. et al.: Polym. Chem., 2014, 9. https://doi.org/10.1039/c3py01213a

[2] Huang X., Brittain W.: Macromolecules, 2001, 34, 3255. https://doi.org/10.1021/ma001670s

[3] Derdar H., Belbachir M., Hennaoui F. et al.: Polym. Sci. B, 2018, 60, 555 https://doi.org/10.1134/S1560090418050056

[4] Derdar H., Belbachir M., Harrane A.: Bull. Chem. React. Eng. Catal., 2019, 14, 69. https://doi.org/10.9767/bcrec. 14.1.2692.69-78 [5] Haoue S., Derdar H., Belbachir M. et al.: Bull. Chem. React. Eng. Catal, 2020, 15, 221. https://doi.org/10.9767/bcrec.15.1.6297.221-230 
[6] Varma R.: Tetrahydron, 2002, 58, 1235.

https://doi.org/10.1016/S0040-4020(01)01216-9

[7] Cervantes R., Mayoral E.: Appl. Clay Sci., 2017, 143, 250.

https://doi.org/10.1016/j.clay.2017.03.033

[8] Ray S., Okamoto M.: Prog. Polym. Sci., 2003, 28, 1539.

https://doi.org/10.1016/i.progpolymsci.2003.08.002

[9] Thomas W., Wu L., Feng Y.: Soil Sci., 1978, 126, 15.

[10] Derdar H., Geoffrey R., Vidhura S. et al.: Polymers, 2020,

12, 1971. https://doi.org/10.3390/polym12091971.

[11] Harrane A., Meghabar R., Belbachir M.: Int. J. Mol. Sci., 2002, 3, 790. https://doi.org/10.3390/i3070790

[12] Baghdadli M., Meghabar R., Belbachir M.: Asian J. Chem. 2016, 28, 1197. https://doi.org/10.14233/ajchem.2016.19139

[13] Meghabar R., Megherbi A., Belbachir M.: Polymer, 2003, 44, 4097. https://doi.org/10.1016/S0032-3861(03)00400-2

[14] Akeb M., Harrane A., Belbachir M.: Green Mater., 2018, 6, 58 https://doi.org/10.1680/jgrma.17.00040

[15] El-Kebir A., Harrane A., Belbachir M.: Arabian J. Sci. Eng., 2016, 41, 2179. https://doi.org/10.1007/s13369-015-1862-z

[16] Derdar H., Meghabar R., Benachour M. et al.: Polym. Sci. A, 2021, 63, 568. https://doi.org/10.1134/S0965545X21050023

[17] Sozer N., Kokini J.: Trends Biotechnol., 2009, 27, 82.

https://doi.org/10.1007/s13197-012-0873-y

[18] Giannini L., Galimberti M., Citterio A., Cozzi D.: Chemistry of Rubber-Organoclay Nanocomposites [in]: Galimberti M. (Ed.),

Rubber-Clay Nanocomposites: Science, Technology and

Application. John Wiley and Sons 2011, p. 127-144.

https://doi.org/10.1002/9781118092866.ch5

[19] Sukumar R., Menon A.: J. Appl. Polym. Sci., 2008, 107, 3476. https://10.1002/app.27469

[20] Murray H.: Appl. Clay Sci., 2000, 17, 207.

https://doi.org/10.1016/S0169-1317(00)00016-8

[21] Guo S., Zhang G., Wang J.: J. Colloid Interface Sci., 2014, 433, 1. https://doi.org/10.1016/j.jcis.2014.07.017

[22] Belver C., Muñoz M., Vicente M.: Chem. Mater., 2002, 14

2033. https://doi.org/10.1021/cm0111736

[23] Solomon D., Swift J., Murphy A.: J. Macromol. Sci. A, 1971,

5, 587. https://doi.org/10.1080/00222337108061046

[24] Wang M., Huang P.: Appl. Clay Sci., 1989, 4, 43.

https://doi.org/10.3390/polym10091002

[25] Zhao S.,, Qiu S., Zheng Y. et al.: Mater. Design, 2011, 32, 957. https://doi.org/10.1016/j.matdes.2010.07.020

[26] Hensen K., Mahaim C., Holderich W.: Appl.Catal. A, 1997, 149, 311. https://doi.org/10.1016/S0926-860X(96)00273-6

[27] Ouis N., Benharrats N., Belbachir M.: Comptes RendusChimie, 2004, 7, 955. https://doi.org/10.1016/j.crci.2004.06.003

[28] Felhi M., Tlili A., Gaied M., Montacer M.: Appl. Clay Sci., 2008, 39, 208. https://doi.org/10.1016/j.clay.2007.06.004

[29] Chandrasekhar S., Ramaswamy S.: Appl. Clay Sci., 2007, 37,

32. https://doi.org/10.1016/j.clay.2006.11.007
[30] Oliveira M., Furtado S. et al.: An. Acad. Bras. Ciênc., 2007, 79, 665 .

https://doi.org/10.1590/S0001-37652007000400008

[31] Bobos J., Duplay J., Rocha J. et al.: Clays Clay Minerals, 2001, 49, 596. https://doi.org/10.1346/CCMN.2001.0490609

[32] Cicel B.: Carpath. Ser. Clays, 1992, 43, 3.

[33] Hernandez M.: Etude de mélanges ternaires époxyde/PMMA/montmorillonite. Élaboration, contrôle de la morphologie et des propriétés, thèse de doctorat, INSA de Lyon, 2007, p. 16-23.

[34] Bensaada N., Ayat M., Meghabar R., Belbachir M.: Curr. Chem. Lett., 2015, 4, 55. https://doi.org/10.5267/j.ccl.2015.3.002 [35] Belbachir M., Harrane A., Meghabar R.: Macromol. Symposia, 2006, 246, 1. https://doi.org/10.1002/masy.200651301

[36] Ayat M., Harrane A., Belbachir M.: Appl. Polym. Sci., 2008, 109, 1476. https://doi.org/10.1002/app.28285

[37] Yahiaoui A., Belbachir M.: Appl. Polym. Sci., 2006, 100, 1681. https://doi.org/10.1002/app.22946

Received: October 01, 2019 / Revised: December 09, 2019 / Accepted: December 12, 2019

\section{АКТИВАЦІЯ ТА ХАРАКТЕРИСТИКА АЛЖИРСЬКОГО КАОЛІНІТУ, НОВОГО І ЕКОБЕЗПЕЧНОГО КАТАЛІЗАТОРА СИНТЕЗУ ПОЛІСТИРЕНУ ТА ПОЛІ(1, 3-ДІОКСОЛАНУ)}

Анотація. Досліджено новий каталізатор, приготований з алжирської глини, та розроблено новий метод синтезу полістиролу та полі(1,3-діоксолану). Показано, щчо модифіковану алжирську глину (Каолініт- $H^{+}$) можна використовувати як екокаталізатор. Каолініт- $H^{+}$являє собою протоннообмінену глину, приготовлену звичайною реакиією обміну. Встановлено, щзо полімеризачія стирену в масі за кімнатноі температури та часі реакиії 3 години дає можливість одержувати продукт з виходом $83 \% .3$ використанням ${ }^{l}$ Н ЯМР визначена молекулярна маса отриманого полістирену, яка становить приблизно 2196 г/моль. При полімеризаиії (1,3діоксолану) за кімнатної температури та часі реакції 3 год отримано продукт з виходом 91\%. Розрахована молекулярна маса отриманого полі(1,3-діоксолана) становить приблизно 573 г/моль. Структуру отриманих полімерів підтверджено Фур 'є-спектроскопією, ${ }^{1}$ Н ЯМР, рентгеноструктурним аналізом та скануючої електронною мікроскопією.

Ключові слова: каолініт- $H^{+}$, алжирська глина, екокаталізатор, полістирен, полі(1,3-діоксолан). 